\title{
Ciliate dynamics in response to changing biotic and abiotic conditions in a large, deep lake (Lake Constance)
}

\author{
Ursula Gaedke ${ }^{1, *}$, Stephen A. Wickham ${ }^{2,3}$ \\ ${ }^{1}$ Institut für Biochemie und Biologie, University of Potsdam, Maulbeerallee 2, 14415 Potsdam, Germany \\ ${ }^{2}$ University of Cologne, Zoological Institute, Weyertal 119, 50923 Cologne, Germany \\ ${ }^{3}$ Present address: Zoological Institute, University of Salzburg, Hellbrunnerstr. 34, 5020 Salzburg, Austria
}

\begin{abstract}
From 1987 to 1998, ciliates and their prey and predator communities in Lake Constance (which is large, deep and meso-eutrophic) were intensively studied as the lake underwent reoligotrophication. Ciliate biomass exhibited the bimodal seasonal distribution typical for mesoeutrophic lakes, with high biomass in spring and summer and low biomass in winter and during the clear-water phase. Cluster analysis produced 9 groups of temporally co-occurring ciliate morphotypes with potentially similar ecological characteristics. The clusters exhibited a larger seasonality than found in the size distribution, showing that size alone failed to capture some ciliate seasonal dynamics. Ciliate biomass declined by approx. $30 \%$ during the $12 \mathrm{yr}$ of study, i.e. considerably less than daphnids (and total phosphorus). This yielded a significant increase in the ratio between summer ciliate and daphnid biomass as re-oligotrophication progressed, in contrast to previous studies. Few indications for a mechanistic link between phosphorus concentrations (which declined 3-fold during the study period) and ciliate biomass or community composition via group-specific food concentrations were found. The relative contribution of 3 of the 9 clusters changed as re-oligotrophication progressed. Ciliate size distribution was related to re-oligotrophication and daphnid biomass in summer. The smallest and largest ciliates gained importance when daphnids decreased, whereas the biomass of large ciliates declined. Generally, summer daphnid biomass had a greater predictive power for attributes of the ciliate community than the other factors studied (phosphorus, prey biomass, copepod biomass). The extent of bottom-up and top-down control of ciliates appeared to be time- and groupspecific. Overall, the ciliate community exhibited remarkably recurrent seasonal patterns, despite major alternations in abiotic and biotic conditions.
\end{abstract}

KEY WORDS: Ciliates · Long-term observations - Bottom-up control · Top-down control · Eutrophication $\cdot$ Daphnids $\cdot$ Copepods

\section{INTRODUCTION}

Dominant plankton groups such as phytoplankton and crustaceans are well known to respond sensitively to external forcing by changes in nutrient availability, climatic conditions or predator abundance (e.g. Sommer et al. 1986, Straile 2000, 2002). Long-term investigations of a population's response to altered environmental conditions or predator and prey densities can provide valuable insight into in situ growth determin- ing factors (Scheffer et al. 2001) and food web interactions. The population dynamics of Protozoa have rarely been investigated in this manner, although their importance for the cycling of matter and energy in pelagic food webs is increasingly recognized (Levinsen \& Nielsen 2002). Understanding protozoan dynamics and species composition represents a challenge, because most ciliate species are subject to intra-guild predation by daphnids. That is, potential top-down and bottom-up control factors (daphnids and phytoplank- 
ton) may be closely linked and subject to external forcing by climate and nutrient changes.

In Lake Constance, which is large, deep and mesoeutrophic, intensive investigations of the planktonic ciliate community revealed recurrent seasonal patterns in ciliate abundances and taxonomic community composition from 1987 to 1989 (Müller 1989, 1991, Müller et al. 1991). Biomass peaks developed in early spring immediately after the onset of phytoplankton growth, and in summer/autumn after the clear-water phase, during which time ciliate biomass was low. In spring, small algivorous ciliates such as Balanion planctonicum were typical, while the summer community was characterized by a somewhat higher variability in taxonomical composition and feeding types (Müller 1989, 1991, Müller et al. 1991). Laboratory studies provided insight into ciliate ingestion and production rates, preferred algal food sources and encystment of ciliates in Lake Constance (Müller \& Weisse 1994, Müller 1996, Weisse \& Müller 1998, Müller \& Schlegel 1999). Studies on the entire pelagic food web of Lake Constance showed that ciliates were the dominant phytoplankton grazers in spring and presumably surpassed the grazing activity of daphnids on annual average (Gaedke \& Straile 1994, Gaedke et al. 2002).

Lake Constance is currently undergoing re-oligotrophication. Total phosphorus during winter mixing $\left(\mathrm{TP}_{\text {mix }}\right)$ has declined from $>80$ to $12 \mu \mathrm{g} \mathrm{P} \mathrm{l}^{-1}$ since 1980 (from 58 to $17 \mu \mathrm{g} \mathrm{P} \mathrm{l}^{-1}$ during the study period, 1987 to 1998) (Güde et al. 1998). Inorganic $P$ concentrations available to algae and bacteria fell below the detection limit throughout the euphotic zone in summer, autumn and, in most oligotrophic years, also in spring. The lake's trophic status has changed from meso-eutrophic to meso-oligotrophic. This change has affected the pelagic community, in particular phytoplankton during summer, but also increasingly at other times of the year (Gaedke 1998a,b, Güde et al. 1998, and literature cited therein). In most recent years, the typical July rebound of phytoplankton after the clear-water phase was retarded until August (U. Gaedke unpubl.). From 1995 onwards summer daphnid biomass was lower than in previous years, especially in July (D. Straile unpubl.). The biomass of daphnids and of various ciliate size classes at individual sampling dates was inversely correlated in late spring and early summer (Gaedke \& Straile 1998), suggesting that the expected negative impact of daphnids on numerous ciliates is relevant under in situ conditions in Lake Constance.

Ciliate abundance and biomass are typically positively correlated with total phosphorus, chl $a$ and Carlson's trophic index (Beaver \& Crisman 1982, 1989, Bays \& Crisman 1983, Pace 1986, Mathes \& Arndt 1994, Pfister et al. 2002, Zingel et al. 2002). However, Gasol et al. (1995) found in a cross-lake comparison no relationship for a range of 3 to $50 \mu \mathrm{g} \mathrm{TP} \mathrm{l}^{-1}$, and a weak one for the range of 0.1 to $16 \mu \mathrm{g} \mathrm{chl} \mathrm{a} \mathrm{l}^{-1}$.

Climate is a second well-established external forcing factor for plankton communities. The study period included both extremely harsh and mild winters, which affected daphnid development in Lake Constance until summer (Straile 2000, 2002). Phytoplankton spring growth was highly predictable from the ambient vertical mixing intensity (Gaedke et al. 1998) that in turn depended on individual weather (wind) events (Bäuerle et al. 1998). This provoked rapid changes in spring algal growth conditions to which ciliate spring growth was closely linked, whereas the decline of ciliate biomass after the spring bloom depended on the development of daphnids and other predators (U. Gaedke \& D. Straile unpubl.).

Daphnids are the most important intra-guild predators of ciliates during summer in Lake Constance (Gaedke \& Straile 1998). Copepods, which dominate crustacean biomass in winter and spring, have been reported to prey heavily on ciliates as well (Sanders \& Wickham 1993, Wickham 1995a, Adrian \& SchneiderOlt 1999, Burns \& Schallenberg 1996). Given their different feeding modes, these 2 groups of crustaceans were considered separately. In Lake Constance, rotifers had $20 \%$ of the ciliate and $<5 \%$ of the crustacean biomass on long-term average (Gaedke et al. 2002), which prevented their further consideration.

The objectives of the present investigation were to elucidate the long-term development (1987 to 1998) of the ciliate community in a large open water body to learn about in situ growth determining factors and food web interactions. More specifically, variation in biomass, size and community structure in relation to the season, trophic and climatic conditions, and prey and predator biomass, were analyzed, as well as changes in the relative importance of ciliates as compared to daphnids. Furthermore, the temporal co-occurrence of the different morphotypes was studied to identify those with potentially similar ecological characteristics.

\section{MATERIALS AND METHODS}

Upper Lake Constance is a large (volume ca. $\left.50 \mathrm{~km}^{3}\right)$, deep $\left(z_{\text {mean }}=101 \mathrm{~m}, z_{\max }=252 \mathrm{~m}\right.$, where $z$ is depth), warm-monomictic lake north of the Alps. Owing to its size $\left(476 \mathrm{~km}^{2}\right)$ and a less pronounced stratification than typically found in smaller lakes, Lake Constance has a relatively deep, well-mixed epilimnion and a large pelagic zone.

All plankton were sampled weekly during the growing season and approximately every 2 wk in winter by a large team of scientists. Samples were collected at a central sampling site of $147 \mathrm{~m}$ depth, in the northwest- 
ern part of Upper Lake Constance (Überlinger See) at a range of depths (in 1987: 0-4, 4-8, 8-12, 12-16, 16-20, 50 and $140 \mathrm{~m} ; 1988$ to 1998: 0-8 and 8-20 m). Ciliate data are available for 2 to 3 times $\mathrm{wk}^{-1}$ from April to mid-June 1991 (Weisse \& Müller 1998). For routine counting, ciliates were fixed with Lugol's solution (Müller 1989). The abundance of all planktonic organisms was assessed using advanced microscopy techniques (e.g. Gaedke 1998a, Weisse \& Müller 1998, Gaedke et al. 2002, and literature cited therein). Ciliates were grouped into 24 morphotypes following Müller (1989), Müller et al. (1991), Weisse \& Müller (1998) and Müller (pers. comm.), which represent either individual species or higher taxonomic units which could be identified by light microscopy (Table 1). Unidentified ciliates were included when considering total biomass but not when working at a higher resolution. The relative share of unidentified ciliates generally amounted to $0-5$ (10)\% of total ciliate biomass. It was higher in $7 \%$ of the sampling dates which were excluded from further consideration. Biovolume was established by measuring cell dimensions. Ciliate biovolume was converted to units of carbon assuming a carbon to fresh-weight ratio of $15.4 \%$ (Weisse \& Müller 1998, for other plankton groups see Gaedke et al. 2002 and literature cited therein). Ciliates were subdivided into 5 size classes according to their largest linear dimension: $<20,20$ to $<35,35$ to $<50,50$ to $<100$ and $>100 \mu \mathrm{m}$ (Müller et al. 1991).

Chl a concentrations were determined spectrophotometrically from hot ethanol extracts and corrected for phaeopigments by acidification (Häse et al. 1998 and literature cited therein). From 1979 to 1998, crustaceans were collected with a Clarke-Bampus sampler

Table 1. Results of cluster analysis with species or morphotypes that could be reliably identified over the 12 yr study, and the clusters to which they belong. Taxonomic groups are subclasses, or in the case of Heterotrichea and Prostomea, classes. Systematics used are those of Lynn \& Small (2000). Feeding types are the particle size-class grazed (pico-, nano- or microplanktonic) and whether the ciliates are primarily interception or filter feeders, based on literature summarized by Foissner et al. (1999) as well as specialized literature (Brown \& Jenkins 1962, Jonsson 1986, Müller 1991, Kivi \& Setälä 1995, Šimek et al. 1995, 1996, Kenter et al. 1996, Jürgens \& Šimek 2000, Weisse et al. 2001). $R^{2}$ values are the proportion shared variance between the species and either the cluster to which they belong, or the cluster where the $\mathrm{R}^{2}$ value is the next highest. Ideally, members of a cluster share almost all their variance with other members of the cluster, while at the same time having very little variance in common with members of other clusters. To improve biomass estimates, some morphotypes were split into $>1$ size class

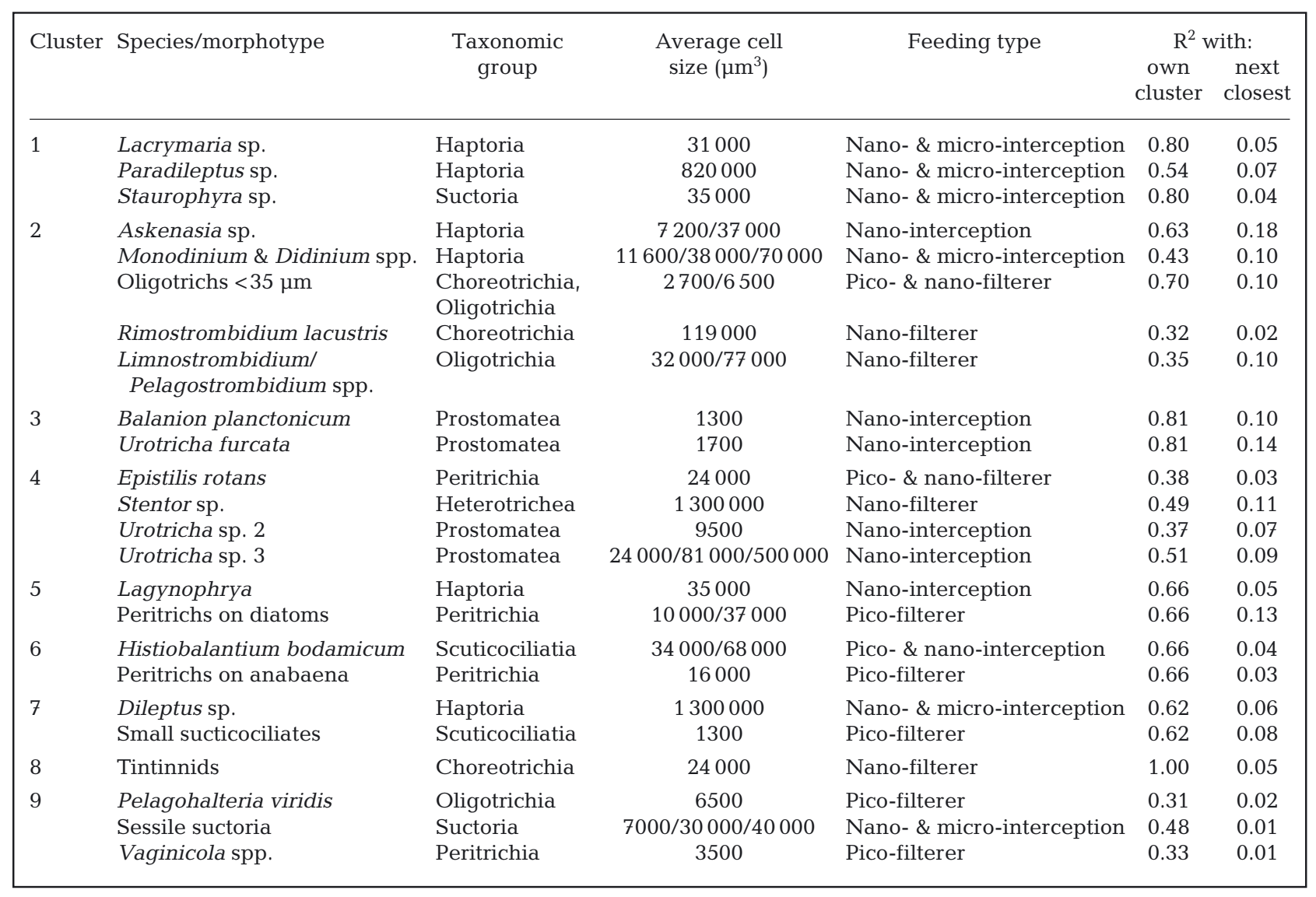


(mesh size $140 \mu \mathrm{m}$ ) by vertical hauls from $140 \mathrm{~m}$ depth (Straile \& Geller 1998 and literature cited therein; D. Straile unpubl.). Seven taxa were routinely identified and separated into up to 5 size classes: Daphnia hyalina, D. galeata, Bosmina sp., Eudiaptomus gracilis, cyclopoid copepods, Leptodora kindtii and Bythotrephes longimanus. Biomass was calculated from length-dry weight relationships established for Lake Constance and assuming carbon content was $50 \%$ of dry weight (Straile \& Geller 1998, Gaedke et al. 2002 and literature cited therein).

The vertical mixing intensity within the upper water column was inferred from a hydrodynamic k- $\varepsilon$ simulation model (Bäuerle et al. 1998, Gaedke et al. 1998). Phytoplankton was classified into more-edible and lessedible, based on studies performed with crustaceans (e.g. Knisely \& Geller 1986) and ciliates (Giani 1991, Müller \& Schlegel 1999) from Lake Constance. The group of edible phytoplankton comprised small individual algal cells, mostly phytoflagellates and small centric diatoms. From the measurements at individual depths, mean values from 0 to $20 \mathrm{~m}$ depth were computed for all plankton biomasses and chlorophyll concentrations by weighting the depth-specific measurements according to the part of the water column they represent.

In order to group the 24 ciliate morphotypes into a smaller number of unique groups, whose members were found approximately at the same time, disjoint (non-hierarchical) cluster analysis was used. The results of this method are sensitive to the initial seeds used and the number of clusters specified (Sharma 1996). Consequently, principal component analysis (PCA) with oblique (promax) rotation was used to generate both the initial cluster seeds and the number of clusters (the number of PCA axes with eigenvalues $>1$ ) (Hair et al. 1984). The correlation matrix was used in order to standardize variance across morphotypes. Unidentified ciliates were omitted from the cluster analysis, as they were likely to be a disparate group, without any consistent temporal patterns.

To assess whether there was an overall relationship between chlorophyll and cluster biomass, an ANCOVA was first conducted, with chlorophyll as a continuous variable, month as a discrete variable and cluster biomass as the dependent variable. A significant chlorophyll effect indicated a significant regression between chlorophyll and the cluster biomass, while a month effect showed a difference in mean cluster biomass between months. An interaction between the two demonstrated that the slope of the regression between chlorophyll and cluster biomass differed between months. In order to reduce the total number of correlations conducted, month-by-month correlations were only conducted if the chlorophyll $\times$ month interaction was significant at $\alpha=0.01$.
Given the longer generation times of crustaceans compared to phytoplankton, correlations against crustacean biomass were conducted for 2 periods (rather than monthly), to reduce the total number of correlations made. The first period was May/June, which covers the time of daphnid mass development and the clear-water phase, whereas the second period, from July to September, was characterized by lower daphnid biomass and a more diverse plankton community (Gaedke \& Straile 1994, Straile \& Geller 1998, Gaedke et al. 2002).

Despite the adaptations described above, a large number of correlations were computed when searching for relationships between the attributes of the ciliate community and potentially influential factors, such as nutrients, climate, and predator and prey densities, using $\mathrm{SAS}^{\circledast}$ and $\mathrm{SPSS}^{\circledast}$. The number of correlations was carefully considered before declaring results significant. All correlations discussed were checked, at least graphically, for dependence on individual sampling years. The Pearson correlation coefficient was used throughout and denoted by $r$ if not otherwise stated. Relative biomasses (proportions, $p$ ) were transformed by $y=2 \times \operatorname{arcsine}\left(p^{0.5}\right)$. The analyses of the potential impact of forcing factors were conducted for the absolute and the relative biomasses and at the level of total biomass, size groups, clusters and morphotypes. Performing many correlations involves a danger of 'picking winners', that is, discussing only those significant correlations that confirm our assumptions. We guarded against this possibility by restricting the correlations to periods or factors that were of particular interest, by conducting ANOVA to first test whether effects were month-specific, and by lowering the critical pvalue to declare correlations significant to below 0.05 .

To compare the rate of change in the size spectrum with that in cluster composition we used the Bray-Curtis similarity index $\mathrm{B}=0.5 \times \Sigma\left|p_{i t 1}-p_{i t 2}\right|$, where $p_{i t 1}$ represents the relative contribution to total biomass of size class (or cluster) $i$ at time $t 1$ (Washington 1984). The index ranges from 0 , where there is no change in composition between time points, to 1 , where no size class or morphotype is present at both time points. Values were disregarded if the sampling interval exceeded $10 \mathrm{~d}$.

\section{RESULTS}

\section{General patterns in ciliate biomass dynamics}

Total ciliate biomass exhibited a recurrent seasonal and interannual pattern during the $12 \mathrm{yr}$ of investigation (Fig. 1). In spring, ciliate biomass increased from low winter values almost simultaneously with phytoplankton and attained peak values of approximately 
$1000 \mathrm{mg} \mathrm{C} \mathrm{m}{ }^{-2}$ (integrated over 0 to $20 \mathrm{~m}$ depth). It declined after the spring bloom during the clear-water phase, but quickly recovered during early summer to a level similar to that in spring. Mean monthly ciliate biomass values were in the range of 50 to $80 \mathrm{mg} \mathrm{C} \mathrm{m}^{-2}$ from December through February and of 400 to $600 \mathrm{mg} \mathrm{C} \mathrm{m}^{-2}$ from April to October, with the exception of June (clear-water phase), when a nadir of $160 \mathrm{mg} \mathrm{C} \mathrm{m}^{-2}$ was reached. In 1993, late spring ciliate biomass was low and declined relatively little during the clear-water phase. In 1994, peak biomasses remained rather low but average spring or summer biomass was not below the long-term average.

Although small in comparison to the intraannual variation, which amounted to a factor of ca. 30 when ignoring extreme values, mean annual ciliate biomass decreased very slightly but significantly (on average $3 \% \mathrm{yr}^{-1}, 30 \%$ in $12 \mathrm{yr}$ ) during the $12 \mathrm{yr}$ period, from $320 \mathrm{mg} \mathrm{C}$ $\mathrm{m}^{-2}$ in the first $2 \mathrm{yr}$ of the study to $230 \mathrm{mg} \mathrm{C} \mathrm{m}^{-2}$ in the final $2 \mathrm{yr}$ (long-term mean: $280 \mathrm{mg} \mathrm{C}$ $\mathrm{m}^{-2}$ ). It exhibited remarkably little interannual variability from this trend (regression of mean $\log$ [ciliate biomass] vs year: $\mathrm{R}^{2}=0.76$, $\mathrm{p}=0.0002$; all values are back-transformed from log-transformed data).

We found no striking correlations between the climate signal and any attribute of the ciliate community (e.g. biomass, size structure, relative composition) beyond early spring. Parameters tested included: vertical mixing intensity of the upper water column, winter minimum water temperature, and the NAO (North Atlantic Oscillation)-index; hence, climate parameters were excluded from further consideration.

\section{Size distribution}

The long-term geometric mean cell size was $5400 \mu^{3}$ when weighted by abundance and $40400 \mu^{3}$ (spring $32000{\mu m^{3}}^{3}$, summer $62000 \mu^{3}$ ) when weighted by biomass. The seasonally resolved ciliate size distribution was fairly constant for the smaller size groups whereas occurrence of very large ciliates (>100 $\mu \mathrm{m}$, e.g. Stentor) was mostly restricted to the summer months (Fig. 2). The smallest size group $(<20 \mu \mathrm{m})$ was most relevant during early spring, as was the size group 50 to $\leq 100 \mu \mathrm{m}$. No major shifts in the size spectrum were observed from March to June prior to the clear-water phase, despite a decrease in total ciliate bio-

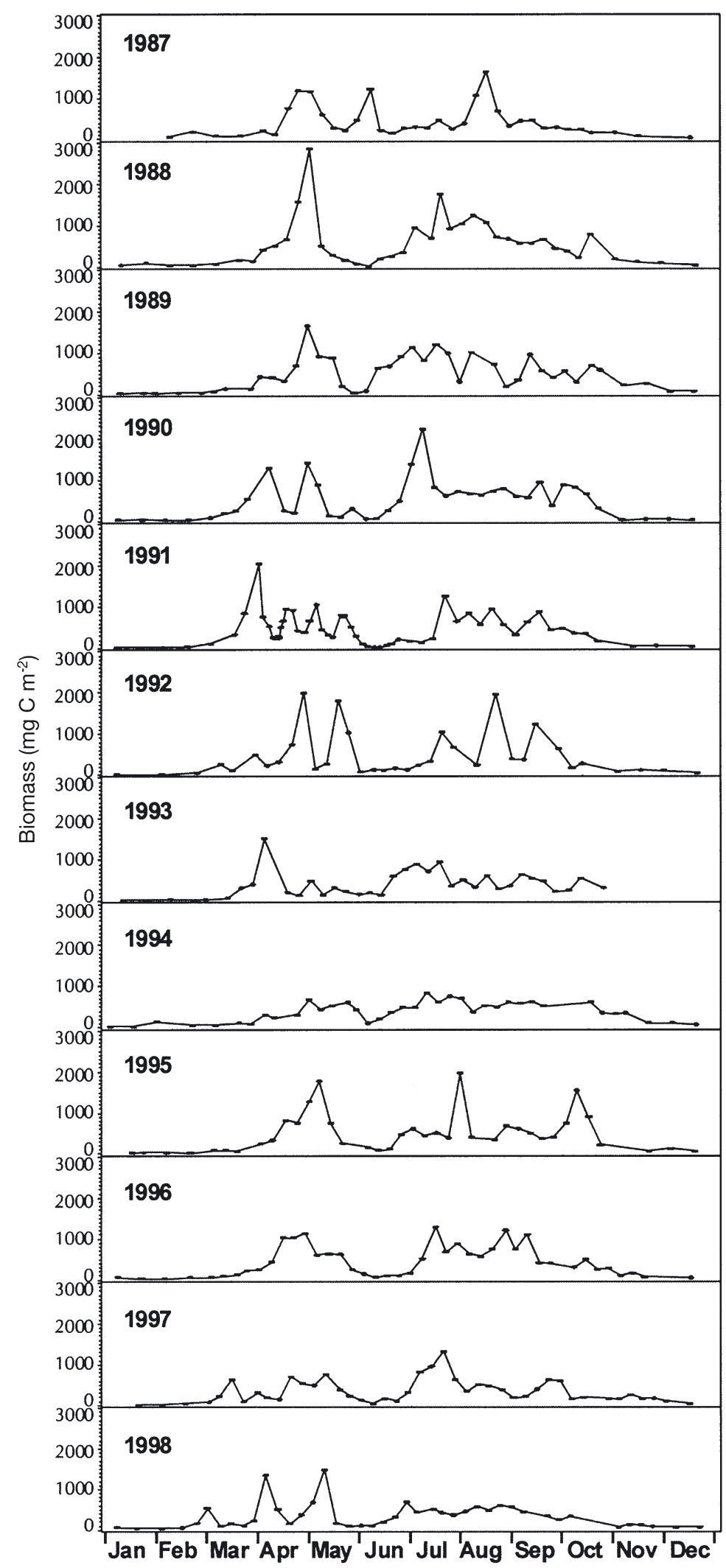

Fig. 1. Time series of the total pelagic ciliate biomass integrated over 0 to $20 \mathrm{~m}$ depth in Lake Constance (1987-1998) 


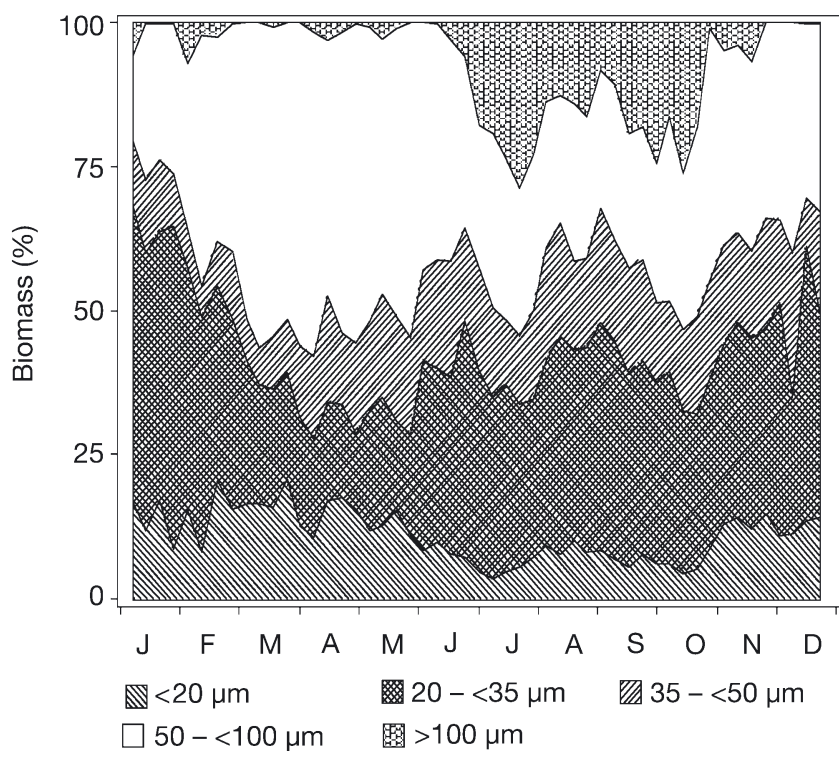

Fig. 2. Seasonal course of the relative size distribution of the ciliate community in Lake Constance averaged over 1987 to 1998. Size classes were defined as $<20,20$ to $<35$, 35 to $<50$, 50 to $<100$ and $>100 \mu \mathrm{m}$

mass by, typically, more than 1 order of magnitude within a few weeks (Fig. 1). The size distribution exhibited moderate inter-annual variability (see 'Correlations with daphnid and copepod biomass' below).

\section{Seasonal co-occurrence}

The cluster analysis suggested 9 groups of ciliates (reduced from the original 24) whose members were found approximately at the same time. The groups were relatively coherent, with no less than $31 \%$ total variance shared between a morphotype and its group, and no more than $18 \%$ shared between a morphotype and the next closest cluster (Table 1). The size of the clusters ranged from 5 morphotypes (Cluster 2, Table 1) to 1 (Cluster 8, tintinnids). Because the grouping was based on a common biomass pattern over time, the clusters were often taxonomically heterogeneous. For example, the 4th cluster consisted of a peritrich, Epistylis rotans, a large heterotrich, Stentor sp. (which appeared in less than $1 \%$ of the samples), and 2 small prostomes, Urotricha spp. 2 and 3. Not surprisingly, however, was that species with similar feeding niches often appeared at the same time and were grouped together (Table 1). Clusters 5, 7 and 9 were the most heterogeneous groups, with both large interception feeders and small filterers. In the case of Cluster 7 , however, the large interception feeder Dileptus sp. only occurred in 11 of the 455 samples, the rest being made up by small, picoplankton-grazing scuticociliates.
Unlike the size-class data, taxonomic clusters showed considerable changes in importance throughout the year (Fig. 3). Cluster 2 made the largest contribution to total ciliate biomass (30 to $45 \%$ annual average; Fig. 3) and comprised ciliates such as Rimostrombidium lacustris and Askenasia sp., which are ubiquitous in lakes (e.g. Foissner et al. 1999, Pfister et al. 2002) and were found throughout the year in Lake Constance. The group was both taxonomically and ecologically similar, with 3 of the 5 being either oligotrichs or the closely related choreotrichs, and with 4 of the 5 having overlapping feeding niches (Table 1). When Cluster 2 declined in importance after the clear-water phase, ciliate diversity increased, with several other clusters (1, 4, 7 and 9) collectively making up between 20 and $32 \%$ of total ciliate biomass in July to October (Fig. 3). Cluster 1 was made up of the large ciliates Lacrymaria sp. and Paradileptus sp., and their increase in importance during summer was also reflected in the increase in the largest ciliate size class (Fig. 2).

Similarity between consecutive sampling dates (measured with the Bray-Curtis similarity index) was smaller in cluster composition than in size composition ( $p<0.001$; Mann-Whitney $U$-test), showing that the relative importance of clusters changed more through time than size classes. The similarity indices did not exhibit distinct seasonal patterns.

Throughout the $12 \mathrm{yr}$ of investigation, the relative share of 3 out of 9 clusters changed (Fig. 4). Cluster 3 (for species composition see Table 1) increased from a yearly average of $2-8 \%$ of total ciliate biomass in the period 1987-1995, to $12-16 \%$ in the period 1996-1998. This was particularly pronounced during September and October. To a lesser extent, Cluster 7 showed a similar pattern, increasing from <0.2-1.2\% in 1987-1995 to $1.1-2.3 \%$ in 1996-1998. Conversely, the tintinnids (Cluster 8) decreased from 10-22\% in the period $1987-1995$ to $9 \%$ in 1996 and $1 \%$ during 1997-1998. The other 6 groups showed no long-term trends in their yearly mean biomass. Thus, the ciliate community, whether measured on a total biomass, size distribution or taxonomic basis, showed only limited changes over the 12 yr period of the study (Figs. 1 \& 4).

\section{Response to reduced $P$ concentrations}

Total $\mathrm{P}$ during winter mixing $\left(\mathrm{TP}_{\text {mix }}\right)$ declined by a factor of 3 , from 58 to $17 \mu \mathrm{g} \mathrm{P}^{-1}$ from 1987 to 1998 . The duration and water depth where concentrations of soluble reactive phosphorus (SRP) fell below the detection limit of 1 to $2 \mu \mathrm{g} \mathrm{l}^{-1}$ greatly increased. No relationship was found between $\mathrm{TP}_{\text {mix }}$ and the proportion of sampling dates with total ciliate biomasses $>1000 \mathrm{mg}$ $\mathrm{C} \mathrm{m}^{-2}$, i.e. the number and height of peaks during 


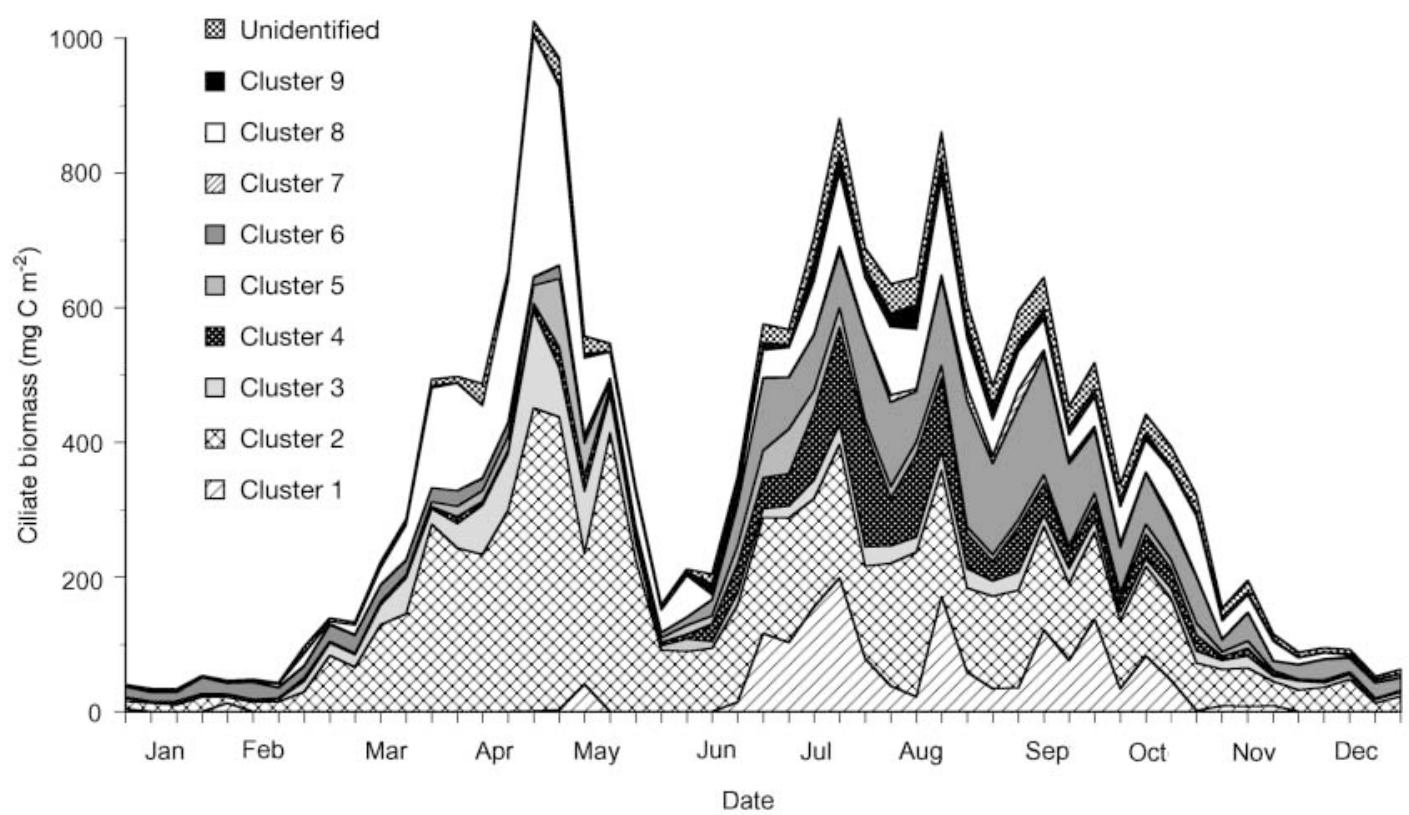

Fig. 3. Seasonal changes of the biomass of individual clusters (weekly means averaged over 1987 to 1998 in 0 to $20 \mathrm{~m}$ depth). See Table 1 for an explanation of cluster membership. Tick marks correspond to weeks

spring and summer were not altered by re-oligotrophication (Fig. 1). Re-oligotrophication affected the size distribution only moderately (Table 2). In absolute and relative importance, the smallest size class gained $(\mathrm{r}=$ -0.70 and $-0.71, p=0.01$ ) and the second largest lost $(\mathrm{r}=0.53$ and $0.57, \mathrm{p}=0.08$ and 0.05$)$ during July to
September, when nutrient limitation was strongest. During the same time interval, Cluster 8 (tintinnids) declined with decreasing $\mathrm{TP}_{\mathrm{mix}}$ in both absolute and relative numbers $(r=0.74$ and 0.73$)$. None of the other 8 clusters were strongly correlated with $\mathrm{TP}_{\text {mix }}$ on either an absolute or relative basis.

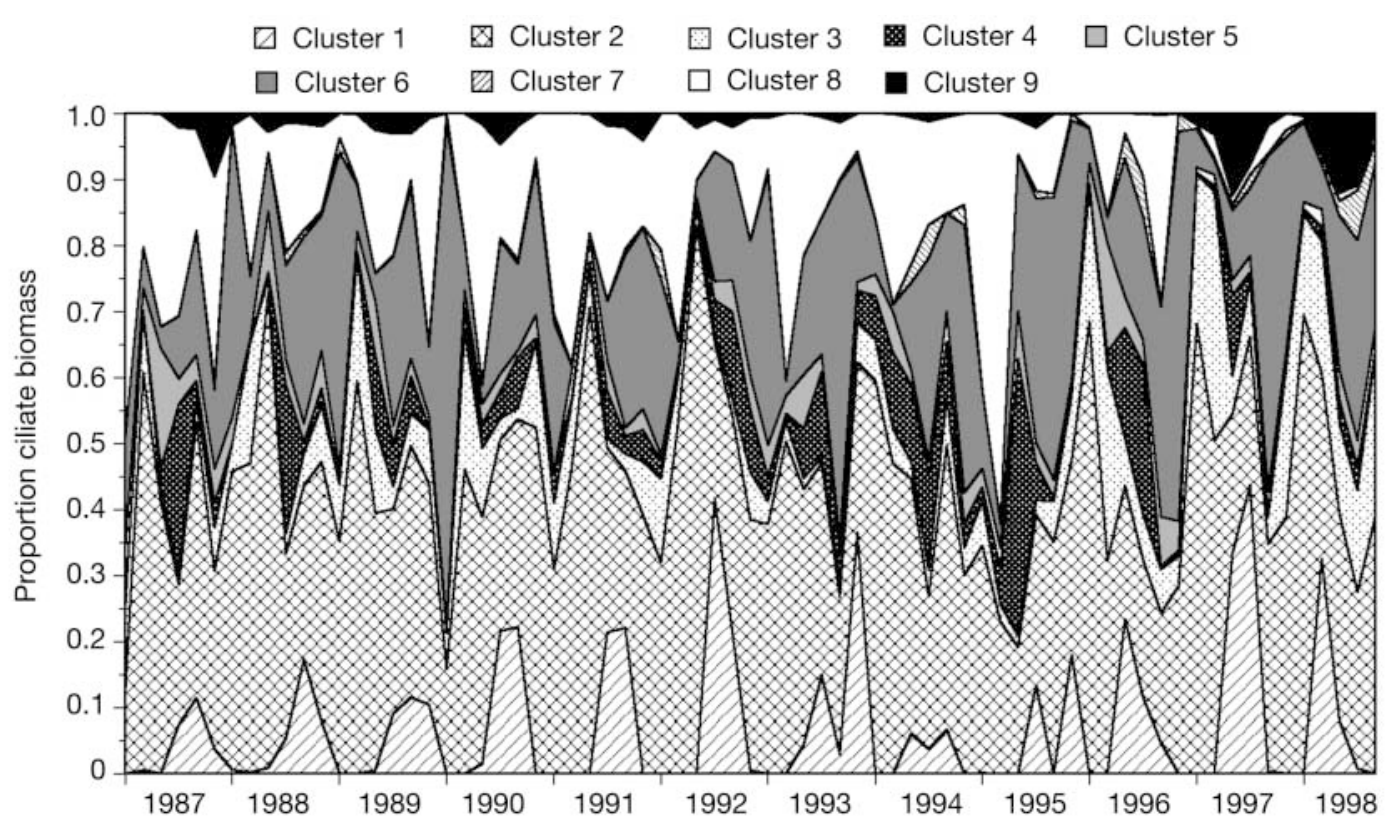

Fig. 4. Long-term observations of the relative contribution of individual clusters to total ciliate biomass. Data were aggregated to bimonthly means to improve the readability of the figure. See Table 1 for an explanation of cluster membership 

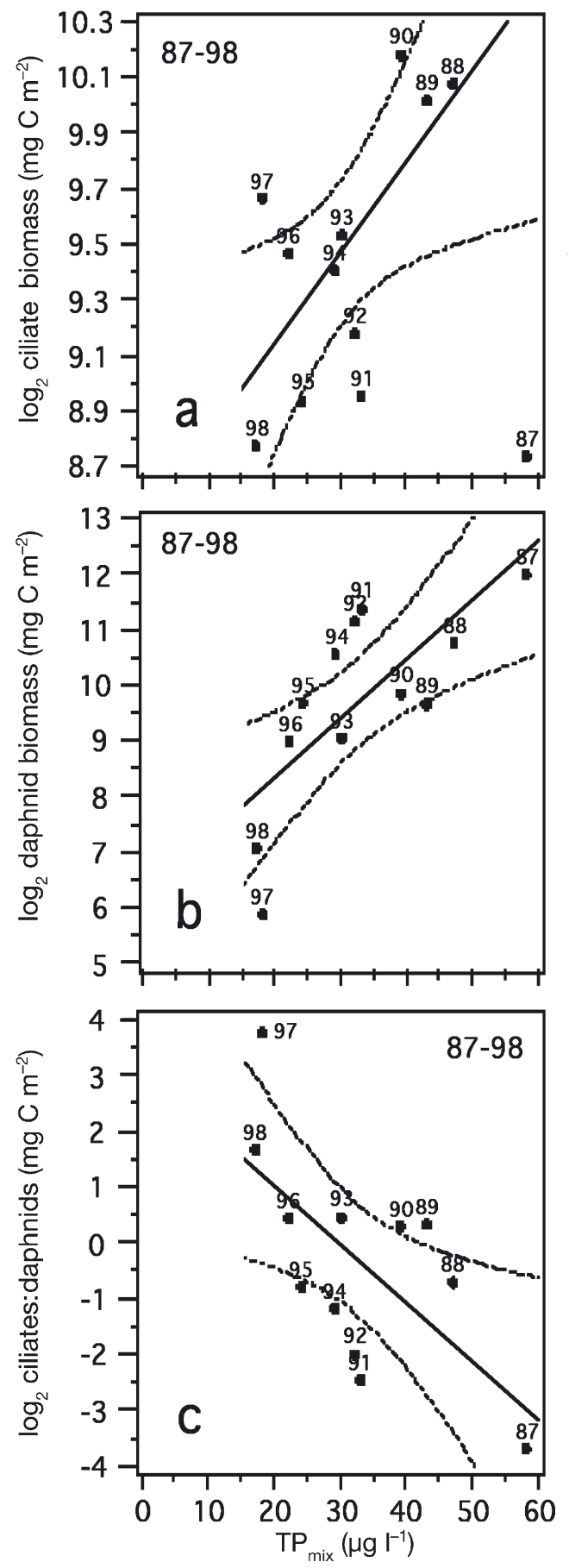

Fig. 5. Correlation between total phosphorus during winter mixing ( $\mathrm{TP}_{\text {mix }}$ ) and (a) the logarithm of total ciliate biomass (only significant when omitting 1987: $\mathrm{r}=0.78, \mathrm{p}=0.005, \mathrm{n}=11$ ), (b) the logarithm of daphnid biomass $(\mathrm{r}=0.74, \mathrm{p}=0.006, \mathrm{n}=12$; without 1987: $r=0.68, p=0.02, n=11$ ) and (c) the logarithm of the ratio between ciliate and daphnid biomass in July $(\mathrm{r}=-0.68$, $\mathrm{p}=0.01, \mathrm{n}=12$; without 1987: $\mathrm{r}=-0.52, \mathrm{p}=0.10, \mathrm{n}=11$ ) in 0 to $20 \mathrm{~m}$ depth. Note that minimum and maximum values of ciliate biomass differed by a factor of 4 and those of daphnids by a factor of 65. The year 1987 was characterized by a low NAOindex, a cold winter, late spring and daphnid development, and an extreme flooding event in late July/early August
The relative contribution of ciliates to total summer zooplankton increased markedly as the re-oligotrophication progressed. Total ciliate biomass declined with $\mathrm{TP}_{\text {mix }}$ in July by a factor of approximately 2 from 1988 to 1990 until 1997-1998 (Fig. 5a), whereas daphnid biomass in July declined at least 10-fold during the study period (Fig. 5b) (which also holds for total crustacean biomass as it was dominated by daphnids during July). This yielded a significant positive correlation between the ratio of ciliate to daphnid biomass with $\mathrm{TP}_{\text {mix }}$ in July (Fig. 5c) and August ( $\mathrm{r}=0.53 \mathrm{p}=0.012$, data not shown). In July 1987, 1991 and 1992 ciliate biomass reached only 7,18 and $25 \%$ of daphnid biomass whereas it surpassed daphnid biomass by a factor of 14 and 3 in July 1997 and 1998, respectively (Fig. 5c).

\section{Correlations with prey biomass}

The most straightforward explanation for a correlation between $\mathrm{TP}_{\text {mix }}$ and ciliate community composition is a change in food quantity and/or quality. However, no strong relationships were found between $\mathrm{TP}_{\text {mix }}$ and the biomass of potential ciliate prey organisms during summer. Chl a concentrations in July declined by a factor of approximately 2 with $\mathrm{TP}_{\text {mix }}(\mathrm{r}=0.82, \mathrm{p}=0.002$, $\mathrm{n}=11$ excluding 1987 and $\mathrm{p}=0.06$ including 1987). Primary production exhibited a declining trend when excluding 1987 ( $\mathrm{r}=0.62, \mathrm{p}=0.06, \mathrm{n}=10$, measurements for 1998 not available) but absolute changes were less than a factor of 2 .

Similarly, relatively few striking correlations between the ciliates and their prey were found (Table 2) after accounting for the expected typical bimodal seasonal distribution of all smaller plankton in meso- and eutrophic lakes with high biomass values in spring and summer and low ones during winter and the clearwater phase. In particular, no significant relationships were established during any month or any seasonal phase between total ciliate biomass and the summed biomass of bacteria, heterotrophic flagellates, autotrophic picoplankton and total or edible algae (the latter except for early spring as both were forced by vertical mixing). There was, however, a positive regression between yearly mean ciliate biomass and yearly mean chlorophyll concentration (log[ciliate biomass $\left.]=1.62+1.25 \log [\mathrm{chl}], \mathrm{R}^{2}=0.73, \mathrm{p}=0.0004\right)$.

The lack of strong relationships between total ciliate biomass and the biomass of potential prey groups may arise from neglecting the differences in prey selection of the various ciliate species. As a result, both the absolute and relative biomass of the 9 clusters were correlated separately against chlorophyll and the biomass of those algae most likely to be edible for ciliates. Regarding chlorophyll, neither the relative nor absolute bio- 
mass of Clusters 1, 7 and 9 (for species composition of clusters see Table 1) showed significant correlations. Cluster 2 was positively correlated with chlorophyll in all months ( $p=0.0001, r=0.81)$, as were Clusters 3 and $5(\mathrm{p}=0.0001$ and $\mathrm{r}=0.62$ for both clusters). Cluster 6 had only a very weak correlation to chlorophyll, but one that was present in all months (chlorophyll effect: $\mathrm{p}=$ $0.081 ; \mathrm{r}=0.57$ ). This weak correlation of the absolute biomass of Cluster 6 resulted in the relative biomass being negatively correlated with chlorophyll in all months $(\mathrm{p}=0.0001, \mathrm{r}=-0.64)$. The relationship of Clusters 4 and 8 with chlorophyll were positive during May, and for Cluster 4 in June, when chlorophyll concentration varied strongly. The relative biomass of these groups did not change with changing chlorophyll during these months ( $p>0.01)$, indicating that these clusters did not benefit disproportionately from higher chlorophyll.

Regressing the absolute and relative biomass of the 9 clusters against the biomass of the 2 edible algal groups (phytoflagellates, and, as a second group, small diatoms and coccales) yields 216 correlations (9 clusters $\times 2$ algal groups $\times 12 \mathrm{mo}$ ). At $\alpha=0.01,12 \%$ (for absolute biomass) and $6 \%$ (relative biomass) of all correlations were significant. Most involved Clusters 2, 3 and 8 and occurred in the period July to September. In this latter period, however, tintinnids were negatively correlated with the 2 edible algae groups in absolute and relative values, whereas the relative biomass of Clusters 3, 7 and 9 correlated positively.

Overall, relatively few indications for a mechanistic link between $\mathrm{TP}_{\text {mix }}$ and ciliate biomass or community composition via group-specific food concentrations were found. This may be partially due to the rapid dynamics of ciliate prey and predators (Fig. 6), and motivated the search for other biomass controlling factors.

\section{Correlations with daphnid and copepod biomass}

The biomass of individual crustacean species responded only weakly to the decline in $\mathrm{TP}_{\text {mix }}$ during the first $15 \mathrm{yr}$ of re-oligotrophication (1979 to 1994, Straile \& Geller 1998). However, from 1995 onwards, summer daphnid biomass (Daphnia hyalina and $D$. galeata) was significantly lower than in previous years. This resulted in tight correlations of monthly averaged daphnid biomasses with $\mathrm{TP}_{\text {mix }}$ in July (Fig. 5b), August and October $\left(\mathrm{r}^{2}\right.$ in the range of 0.61 to $0.74, \mathrm{p}$ in the range of 0.008 to 0.035 ) during 1987 to 1998 . Hence, potential bottom-up effects on ciliate population dynamics are confounded by a decrease in the daphnid biomass presumably exerting top-down control. In addition, copepods, which did not vary markedly, may influence ciliate dynamics and were considered as well.

Around the clear-water phase in May/June, low ciliate biomasses coincided with high daphnid biomass (although the reverse did not always occur) (Fig. 6). During July to September, no relationship between total ciliate biomass and daphnid or copepod biomass was found, nor with copepod biomass in May/June (Table 2). However, the susceptibility of ciliate species to daphnids and copepods may differ, which motivated a search for size- or group-specific responses of ciliates. In May/June, the absolute biomasses of the different size classes were negatively correlated with daphnid biomass, which also holds true for the smallest size class $(<20 \mu \mathrm{m})$ for July to September (Table 2$)$.

Correlations of the absolute and relative biomass of the 9 clusters with daphnid and copepod biomass were also calculated for May/June and July to September, of which $28 \%$ were significant at $\alpha=0.01$. In the

Table 2. Overview of significant positive and negative correlations between attributes of the ciliate community and potentially influential factors during either the growing season, the period May/June (M/J) or July to September (J-S; for details see 'Results'). nd: not determined. It was not meaningful to perform the computations. *'See 'Results' for details. 'Prey biomass' summarizes findings obtained from correlations against total prey biomass, biomass of individual prey groups and chlorophyll. TP: total phosphorus

\begin{tabular}{|c|c|c|c|c|c|c|c|c|}
\hline & \multicolumn{2}{|c|}{$-\mathrm{TP}$} & \multicolumn{2}{|c|}{$\ldots$ Prey biomass } & \multicolumn{2}{|c|}{-Daphnid biomass } & \multicolumn{2}{|c|}{ — Copepod biomass - } \\
\hline & Positive & Negative & Positive & Negative & Positive & Negative & Positive & Negative \\
\hline Total ciliate biomass & $*$ & & * & & & * & & \\
\hline Size-class biomass & Class 4 & Class 1 & & & & $\begin{array}{l}\text { M/J Class 1-5; } \\
\text { J-S Class } 1\end{array}$ & & \\
\hline Cluster biomass & Cluster 8 & & Clusters 2, 3, 5 & Cluster 8* & J-S Cluster 8 & $\begin{array}{c}\text { M/J Cluster 2, } \\
3,5,8 ; \\
\text { J-S Cluster } 3\end{array}$ & & $\begin{array}{l}\text { M/J Cluster } 6 ; \\
\text { J-S Clusters } 3,4\end{array}$ \\
\hline $\begin{array}{l}\text { Relative share of } \\
\text { size classes }\end{array}$ & & Class 1 & nd & nd & Class 4 & Class 1, 5 & & \\
\hline $\begin{array}{l}\text { Relative share } \\
\text { of clusters }\end{array}$ & Cluster 8 & & $\begin{array}{l}\text { Clusters } 2,3,5 \\
\quad(7,9)\end{array}$ & Clusters 6,8 & $\begin{array}{l}\text { M/J Cluster 2; } \\
\text { J-S Cluster } 8\end{array}$ & $\begin{array}{c}\mathrm{M} / \mathrm{J} \text { Clusters } \\
3,5,8 ; \\
\mathrm{J}-\mathrm{S} \text { Cluster } 3\end{array}$ & $\begin{array}{c}\mathrm{M} / \mathrm{J} \\
\text { Cluster } 2\end{array}$ & $\begin{array}{c}\text { M/J Clusters } \\
4,6 ; \mathrm{J}-\mathrm{S} \\
\text { Cluster } 4\end{array}$ \\
\hline
\end{tabular}


May/June period, Clusters 2, 3, 5 and 8 were negatively correlated with daphnid biomass and Cluster 6 with copepod biomass. The strength of these relationships differed among clusters, which affected relative biomass correlations. The relative biomass of Cluster 2 correlated positively with both daphnid and copepod biomass, while those of Clusters 3, 5 and 8 were negatively related to daphnid biomass and those of Clusters 4 and 6 with copepods.
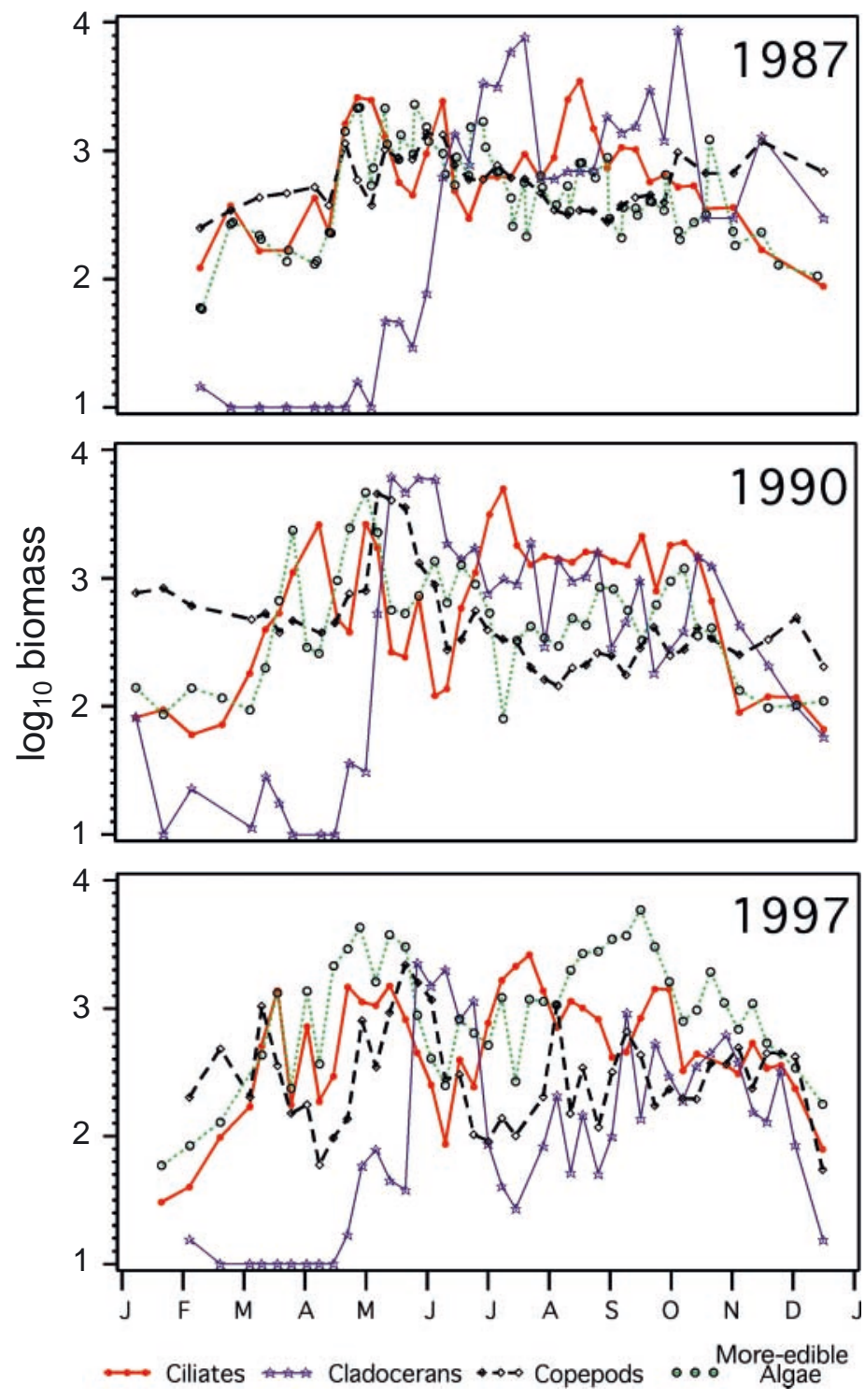

Fig. 6. Seasonal course of the biomass of more-edible algae, ciliates, cladocerans (daphnids and Bosmina and cyclopoid and calanoid copepods for the years 1987 (coldest winter, highest daphnid biomass in July), 1990 (warmest winter, intermediate daphnid biomass in July) and 1997 (intermediate winter, lowest daphnid biomass in July). To improve the clarity of the figure, biomasses of cladocerans below $1 \mathrm{mg} \mathrm{C}$ $\mathrm{m}^{-2}$ in early spring are not shown
The second period considered was July to September; when daphnid biomass was lower, the ciliate community was more diverse, and the calanoid copepod Eudiaptomus gracilis gained importance in comparison to cyclopoid copepods. We found fewer significant correlations than in early summer. Only Cluster 3 was negatively correlated with the daphnids, while Clusters 3 and 4 were negatively correlated with copepods. Cluster 8, the tintinnids, was in this period positively, instead of negatively, correlated with daphnid biomass $(\mathrm{r}=0.31, \mathrm{p}=0.0007)$. As a result, the relative biomass of the tintinnids was also positively correlated with daphnid biomass, while Cluster 3 was negatively correlated. Only the relative biomass of Cluster 4 decreased while copepod biomass increased, indicating that copepods had little influence on ciliate community composition during July to September.

Daphnid biomass altered the relative size distribution of ciliates, whereas copepods had no measurable impact on size structure. The daphnid effect was most pronounced during July (Fig. 7) when daphnids and phytoplankton exhibited the largest interannual changes, but began in May/June and prevailed in a diminished form until September. The contribution of the smallest ciliate size group $(<20 \mu \mathrm{m})$ increased significantly with decreasing daphnid biomass (Table 2, $\mathrm{r}=-0.46, \mathrm{p}<0.0001, \mathrm{n}=121$ for individual values from July to September) whereas the contributions of the 20 to 35 and 35 to $50 \mu \mathrm{m}$ size classes were, at most, weakly correlated. In contrast, the relative biomass of the second largest group (50 to $\leq 100 \mu \mathrm{m}$ ) decreased with daphnid biomass from ca. 40 to $10 \%(r=0.32$, $\mathrm{p}=$ $0.0003)$, whereas the relative contribution of the largest ciliate size class $(>100 \mu \mathrm{m})$ increased while daphnids declined $(r=-0.27, p=0.01)$. To conclude, summer daphnid biomass had a greater predictive power for various attributes of the ciliate community than the other factors studied ( $\mathrm{TP}_{\text {mix }}$ prey biomass, copepods) (Table 2).

\section{DISCUSSION}

During our period of investigation (1987 to 1998), overall seasonal patterns in ciliate population dynamics and taxonomic community composition largely resembled those described by Müller et al. (1991) for the years 1987 to 1989 . This is remarkable, as not only did climate conditions in these $3 \mathrm{yr}$ strongly deviate from each other, but alterations in climate and nutrient conditions, phytoplankton species composition and daphnid biomass occurred during the $12 \mathrm{yr}$ of observations. The seasonal and interannual variability in these parameters was used to gain new insights into the in situ growth-controlling factors of the ciliate community. 
Re-oligotrophication is likely to affect the bottom-up and top-down control of the ciliate community simultaneously, given that daphnids both prey upon, and compete with, numerous ciliate species (Sanders \& Wickham 1993, Wickham \& Gilbert 1993). It has been shown experimentally that the main interaction between Daphnia spp. and ciliates is predation, rather than competition for shared algal resources, and that relatively low daphnid abundances can produce significant ciliate mortality, even when changes in algal biomass cannot be detected (Pace \& Funke 1991, Wickham \& Gilbert 1991, 1993). In accordance, the present study yielded tighter correlations between ciliate community composition and daphnid biomass than their prey biomass or $\mathrm{TP}_{\text {mix }}$ (Table 2), suggesting a stronger top-down than bottom-up control of ciliates in Lake Constance. This conclusion, however, needs to be tempered by the following considerations:

- In observational data sets, causality may not be simply inferred from correlation without consideration of alternative explanations.

- The strength of top-down control may have varied more widely than that of bottom-up control during our period of observation. In July, mean chlorophyll concentration, biovolume of edible and total phytoplankton, and primary production exhibited an inter-annual variability by a factor of 2 to 3 (Gaedke 1998a,b, Häse et al. 1998), whereas minimum and maximum daphnid biomass differed by a factor of 65 .

- Under low nutrient concentrations, algal food quality may decline due to low concentrations of substances relevant for growth of herbivores (Anderson \& Pond 2000). This has already been demonstrated for Lake Constance (Wacker \& von Elert 2001, Gaedke et al. 2002) and numerous other systems (e.g. Tessier \& Woodruff 2002). Beyond edibility inferred from morphology, algal food quality was not measured continuously in Lake Constance, which prevented further analyses of this potentially influential factor on bottom-up control of ciliates. However, the share of ciliate species
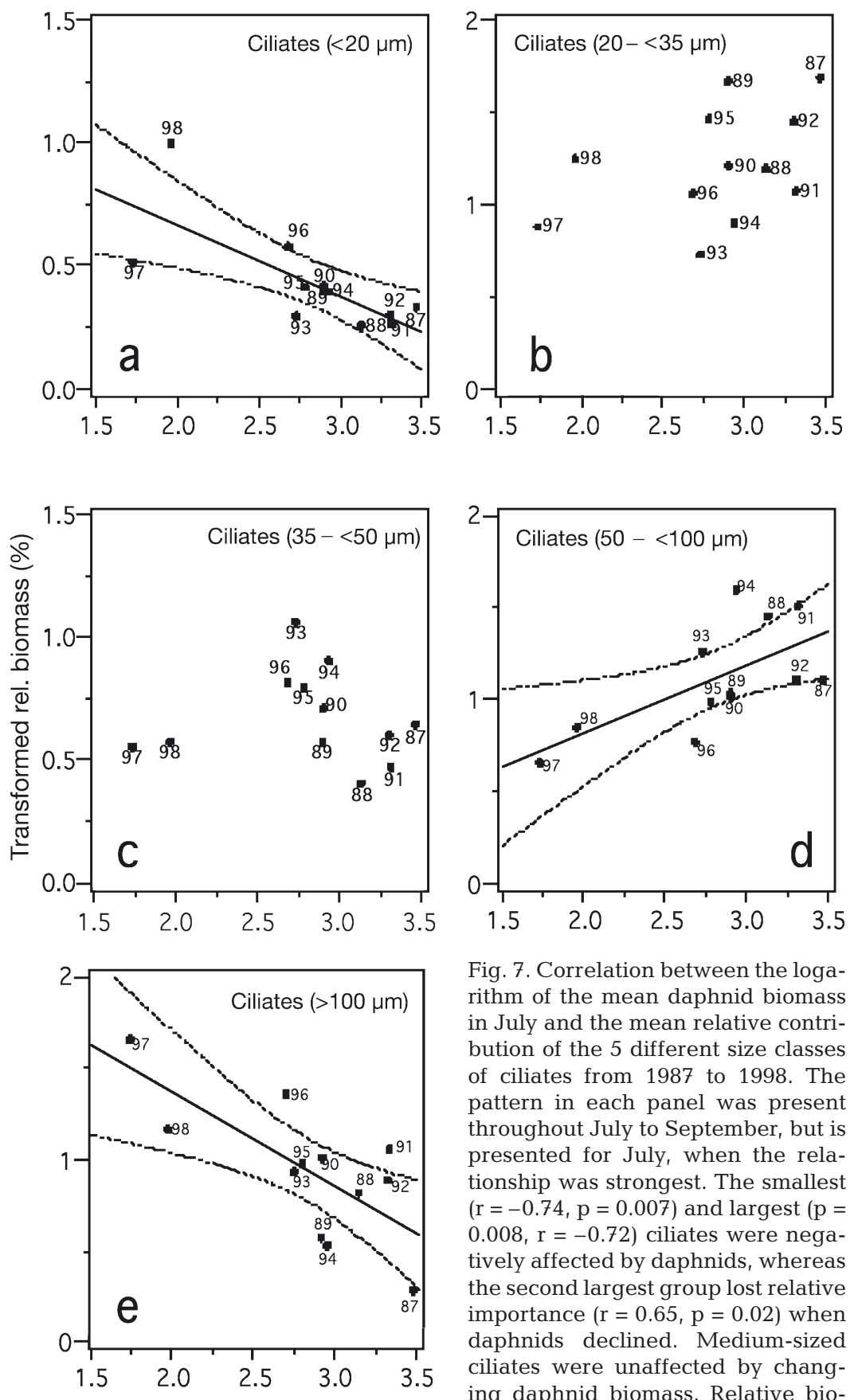

Fig. 7. Correlation between the logarithm of the mean daphnid biomass in July and the mean relative contribution of the 5 different size classes of ciliates from 1987 to 1998. The pattern in each panel was present throughout July to September, but is presented for July, when the relationship was strongest. The smallest $(\mathrm{r}=-0.74, \mathrm{p}=0.007)$ and largest $(\mathrm{p}=$ $0.008, r=-0.72$ ) ciliates were negatively affected by daphnids, whereas the second largest group lost relative importance $(\mathrm{r}=0.65, \mathrm{p}=0.02)$ when daphnids declined. Medium-sized ciliates were unaffected by changing daphnid biomass. Relative biomasses (proportions, $p$ ) were transformed by $y=2 \times \operatorname{arcsine}\left(p^{0.5}\right)$

$$
\log _{10} \text { daphnid biomass (mg C m²) }
$$

that supplement their algivorous diet with P-rich bacteria or other zooplankton increased from spring to summer, which may be attributed to pronounced Pdepletion in phytoplankton during summer, yielding P-deficiency in purely algivorous consumers (Hochstädter 2000, Gaedke et al. 2002). In addition, bacterivores increased relative to algivores during summer as re-oligotrophication progressed: From July to 
September the contribution of Cluster 7, which was largely made up of small scuticociliates known to feed mainly on picoplankton (Šimek et al. 1994, 1995), increased from an average of $0.4 \%$ from 1987 to 1993 to $3 \%$ in the $5 \mathrm{yr}$ thereafter. Tintinnids, which graze on both auto- and heterotrophs in the nano- to micro-size range (Stoecker \& Evans 1985, Stoecker et al. 1995), did the opposite, decreasing from an average of $16 \%$ in the period from 1987 to 1994 , then $3 \%$ thereafter.

- The decline in ciliate biomass in July with $\mathrm{TP}_{\text {mix }}$ (Fig. 5a) is presumably directly related to the concomitant decrease in chlorophyll concentrations and primary production, rather than to enlarged topdown control, because daphnid biomass declined strongly in July during the most oligotrophic years. Its significance, however, relies crucially on 1988 to 1990 data, which belonged to the most eutrophic but also climatically mildest years on record.

- The ciliate community comprises numerous species which may greatly differ in their extent of bottom-up and top-down control. This demands a separate consideration of the different size classes, clusters and time periods.

Indications for bottom-up control were strongest for the most abundant cluster (Cluster 2) comprising ubiquitous species such as Rimostrombidium lacustris and Askenasia sp. The cluster was positively and strongly $(r=0.81)$ correlated with chlorophyll at all times, and uncorrelated with daphnid biomass from July to September. The negative correlation with daphnids during May-June was less than for other groups, yielding a relative increase of Cluster 2. This was somewhat unexpected, given that the oligotrichs and Askenasia sp. of Cluster 2 can be under strong predation control by daphnids and copepods (Jack \& Gilbert 1993, Wickham \& Gilbert 1993, Wiackowski et al. 1994, Wickham 1995a,b).

The vulnerability of ciliates to cladocerans is partly size-dependent (Jack \& Gilbert 1993, Wiackowski et al. 1994), which may explain the decline of the even smaller ciliates of Cluster 3 (Balanion planctonicum and Urotricha furcata) in both absolute and relative abundance in May-June (Fig. 3), indicating that they were at a comparative disadvantage relative to other ciliates. They correlated throughout the season positively with chlorophyll and negatively with daphnids (and copepods from July to September). They were most likely under both predation and exploitative competition from daphnids (i.e. under top-down and bottom-up control) as they graze the same small nanoplanktonic algae as daphnids (Weisse et al. 2001) and are in a size range (approximately 15 to 30 $\mu \mathrm{m})$ optimally grazed by daphnids (Jack \& Gilbert 1993).
Overall, correlations between ciliates and daphnid biomass were more frequent during May-June, whereas correlations with prey parameters occurred more often from July to September, suggesting a shift in dominance of top-down to bottom-up control. Attributes of the ciliate community were more often correlated with daphnid than with copepod biomass. This may be explicable by the longer generation times of copepods, which dampens their numerical response, and by the higher biomass of daphnids overruling potential copepod effects. It disagrees indirectly with results obtained for lakes in New Zealand, where copepods were more effective consumers of protozoa than cladocerans (Burns \& Schallenberg 1996). However, ciliate abundance and community composition differed greatly from those in Lake Constance where biomass of Eudiaptomus gracilis was more than an order of magnitude lower than those provoking a distinct decline in ciliates in an experimental study (Adrian \& Schneider-Olt 1999). Predation rates of calanoid and cyclopoid copepods are known to differ (Burns \& Gilbert 1993, Wickham 1995a, Adrian \& Schneider-Olt 1999). Nevertheless, we did not distinguish between these 2 groups in our statistical analysis since cyclopoids clearly dominated in spring, and during summer when both groups were of more equal importance, copepods as a whole contributed only around $20 \%$ to total crustacean biomass (Straile \& Geller 1998).

The ciliate size distribution exhibited only moderate seasonal changes but its long-term trend was related to daphnid biomass in a remarkable way (Fig. 7). Changes occurred mostly from 1995 onwards when daphnids declined rapidly. Small (and, partly, extremely large) ciliates benefited relatively from low daphnid biomass, whereas medium-sized ones remained unaltered and large ones lost importance. This pattern may be explained by large ciliates (50 to $100 \mu \mathrm{m}$, typified by the tintinnids of Cluster 8) being competitors which decreased with daphnids as algal resources declined. Medium-sized ciliates are both prey of, and competitors with, daphnids, and were thereby released from predation pressure but had reduced resources as both daphnid and algal biomass declined. Small ciliates (typified by the scuticociliates in Cluster 7) are better prey for daphnids (Jack \& Gilbert 1993) and are more likely to graze the picosize class (Šimek et al. 1995), which reduces their niche overlap with daphnids. They could presumably counterbalance effects arising from P-depleted algae (Hochstädter 2000) by bacterivory and experience less grazing pressure owing to reduced daphnid biomass. The largest size class $(>100 \mu \mathrm{m})$, as well as Clusters 1 and 9 (made up of ciliates such as Lacrymaria, Paradileptus and Dileptus), while in part algivorous, are also predacious, feeding on other ciliates, rotifers 
and large algae (Brown \& Jenkins 1962, Foissner et al. 1999). They were, therefore, less likely to be competitors with, or prey of, cladocerans, and in fact, with the exception of July, had weak or no correlations with cladoceran biomass. They increased in late summer, when their putative prey was more abundant.

In summer, protozoans gained importance compared to metazoans under increasingly oligotrophic conditions (Fig. 5c). During half of the study years, ciliate biomass in July surpassed that of daphnids, showing that ciliates exerted a major grazing pressure on phytoplankton, not only in spring but increasingly also in summer, given the higher weight-specific grazing rates of the smaller-sized ciliates. In contrast, crosslake comparisons in Florida, Germany and Finland found that decreasing trophic status resulted in proportionally lower ciliate biomass (Bays \& Crisman 1983, Beaver \& Crisman 1989, Mathes \& Arndt 1994 for the spring peak, Zingel et al. 2002). However, the relative contribution of ciliates to total zooplankton biomass did not vary with trophic status in a study of Quebec lakes (Pace 1986).

In Lake Constance, the ciliate size spectrum changed towards smaller ciliates as re-oligotrophication progressed, whereas the opposite was found in the studies in Finland and Florida (Beaver \& Crisman 1982, 1989, Zingel et al. 2002). In oligotrophic systems, bacterial biomass may be too low to sustain small bacterivorous ciliates (Beaver \& Crisman 1982), but in Lake Constance, numerous small ciliates are predominantly algivorous (Müller et al. 1991). The increasing importance of small ciliates at lower daphnid abundances found in this study fits well with numerous other investigations on the feeding ecology of these organisms.

The strength of decline of ciliate biomass during summer agrees with expectations based on the reduction in primary production (Häse et al. 1998). In contrast, the decrease in daphnid biomass in the most oligotrophic years in Lake Constance is more pronounced than expected from simple resource quantification, suggesting further food web interactions and competitive replacement, subjects which are being addressed separately (Stich in press, D. Straile et al. unpubl.). It was not fully compensated by other cladocerans or copepods. The response of ciliates to altered trophic conditions appears sensitive to the simultaneous alternations in the phytoplankton and zooplankton communities which, in turn, depend on trophic conditions in a complex, non-linear manner. This weakens a direct relationship between ciliates and trophic conditions, and may imply a relative minimum in the importance of ciliates in meso-eutrophic systems and maxima under oligotrophic and highly eutrophic conditions where growth of larger daphnids is hampered.
In summary, we found little responsiveness of the ciliate community in Lake Constance to the various external forcing factors considered, despite inspecting a multitude of potentially influential factors. Both the predators and prey of ciliates underwent important changes which were not proportionally reflected by the ciliate community, although ciliates are major and, at times, dominant herbivores. This remarkable resistance of ciliates to the external forcing present in Lake Constance may be attributed to (1) more indirect dependence on nutrient concentrations than phytoplankton, (2) a high proportion of relatively ubiquitous generalists, (3) effects of the high functional diversity within ciliates (U. Gaedke unpubl.), and (4) the fact that as resources declined, so did predation pressure. Determining whether ciliates are generally more resistant to external forcing than other groups will require similar long-term datasets.

Acknowledgements. Data acquisition was mostly performed within the Special Collaborative Program (SFB) 248 'Cycling of Matter in Lake Constance', supported by Deutsche Forschungsgemeinschaft. Measurements of ciliate abundance were initiated by Helga Müller and Anne Schöne (1987 to 1991) and continued by Stephan Wölfl and Sabine Schmidt-Halewitz. Measurements of crustacean abundance were started by Walter Geller and continued by Dietmar Straile. Phytoplankton measurements were initiated by Ulrich Sommer. Silke Hochstädter established the ciliate data set and performed computations, which greatly stimulated this study. Stephan Saumweber supported the data handling. Rita Adrian, Elanor Bell, Ernst Cleven, Helga Müller, Guntram Weithoff, 2 anonymous referees and the editor, Robert W. Sanders, provided valuable comments on earlier versions of the manuscript.

\section{LITERATURE CITED}

Adrian R, Schneider-Olt B (1999) Top-down effects of crustacean zooplankton on pelagic microorganisms in a mesotrophic lake. J Plankton Res 21:2175-2190

Anderson TR, Pond DW (2000) Stoichiometric theory extended to micronutrients: comparison of the roles of essential fatty acids, carbon, and nitrogen in the nutrition of marine copepods. Limnol Oceanogr 45:1162-1167

Bäuerle E, Ollinger D, Ilmberger J (1998) Some meterological, hydrological and hydrodynamical aspects of Upper Lake Constance. Arch Hydrobiol Spec Iss Adv Limnol 53:31-83

Bays JS, Crisman TL (1983) Zooplankton and trophic state relationships in Florida lakes. Can J Fish Aquat Sci 40: 1813-1819

Beaver JR, Crisman TL (1982) The trophic response of ciliated protozoans in freshwater lakes. Limnol Oceanogr 27: 246-253

Beaver JR, Crisman TL (1989) Analysis of the community structure of planktonic ciliated protozoa relative to trophic state in Florida lakes. Hydrobiologia 174:177-184

Brown HP, Jenkins MM (1962) A protozoan (Dileptus; Ciliata) predatory on metazoa. Science 136:710

Burns C, Gilbert JJ (1993) Predation on ciliates by freshwater calanoid copepods: rates of predation and relative vulnerabilities of prey. Freshw Biol 30:377-393 
Burns CW, Schallenberg M (1996) Relative impacts of copepods, cladocerans and nutrients on the microbial food web of a mesotrophic lake. J Plankton Res 18:683-714

Foissner W, Berger H, Schaumburg J (1999) Identification and ecology of limnetic plankton ciliates. Informationsberichte des Bayer. Landesamtes für Wasserwirtschaft, Munich

Gaedke U (1998a) Functional and taxonomical properties of the phytoplankton community: inter-annual variability and response to re-oligotrophication. Arch Hydrobiol Spec Iss Adv Limnol 53:119-141

Gaedke U (1998b) The response of the pelagic community of a large and deep lake (L. Constance) to reoligotrophication: evidence for scale-dependent hierarchical patterns. Arch Hydrobiol Spec Iss Adv Limnol 53:317-333

Gaedke U, Straile D (1994) Seasonal changes of the quantitative importance of protozoans in a large lake - an ecosystem approach using mass-balanced carbon flow diagrams. Mar Microb Food Webs 8:163-188

Gaedke U, Straile D (1998) Daphnids: keystone species for the pelagic food web structure and energy flow - a body size related analysis linking seasonal changes on the population and ecosystem level. Arch Hydrobiol Spec Iss Adv Limnol 53:587-610

Gaedke U, Ollinger D, Bäuerle E, Straile D (1998) The impact of weather conditions on the seasonal plankton development. Arch Hydrobiol Spec Iss Adv Limnol 53:565-585

Gaedke U, Hochstädter S, Straile D (2002) Interplay between energy limitation and nutritional deficiency: empirical data and food web models. Ecol Monogr 72:251-270

Gasol JM, Simons AM, Kalff J (1995) Patterns in the top-down regulation of heterotrophic nanoflagellates in temperate lakes. J Plankton Res 17(10):1879-1903

Giani A (1991) Implications of phytoplankton chemical composition for zooplankton production: experimental evidence. Oecologia 87:409-416

Güde H, Rossknecht H, Wagner G (1998) Anthropogenic impacts on the trophic state of Lake Constance during the 20th century. Arch Hydrobiol Spec Iss Adv Limnol 53: 85-108

Hair JF Jr, Anderson RE, Tatham RL, Grablowsky BJ (1984) Multivariate data analysis with readings. Macmillan Publishing, New York

Häse C, Gaedke U, Beese B, Seifried A, Tilzer M (1998) Phytoplankton response to reoligotrophication in large and deep Lake Constance: photosynthetic activity and chlorophyll concentration. Arch Hydrobiol Spec Iss Adv Limnol 53:159-178

Hochstädter S (2000) Seasonal changes of C:P-ratios of seston, bacteria, phytoplankton and zooplankton in a deep, mesotrophic lake. Freshw Biol 44:453-464

Jack J, Gilbert JJ (1993) Susceptibilities of different-sized ciliates to direct suppression by small and large cladocerans. Freshw Biol 29:19-29

Jonsson PR (1986) Particle size selection, feeding rates and growth dynamics of marine planktonic oligotrichous ciliates (Ciliophora: Oligotrichina). Mar Ecol Prog Ser 33: 265-277

Jürgens K, Šimek K (2000) Functional response and particle size selection of Halteria cf. grandinella, a common freshwater oligotrichous ciliate. Aquat Microb Ecol 22:57-68

Kenter U, Zimmermann U, Müller H (1996) Grazing rates of the freshwater ciliate Balanion planctonicum determined by flow cytometery. J Plankton Res 18:1047-1053

Kivi K, Setälä O (1995) Simultaneous measurement of food particle selection and clearance rates of planktonic oligotrich ciliates (Ciliophora: Oligotrichina). Mar Ecol Prog Ser 119:125-137
Knisely K, Geller W (1986) Selective feeding of four zooplankton species on natural lake phytoplankton. Oecologia 69:86-94

Levinsen H, Nielsen TG (2002) The trophic role of marine pelagic ciliates and heterotrophic dinoflagellates in artic and temperate coastal ecosystems: a cross-latitude comparison. Limnol Oceanogr 47:427-439

Lynn DH, Small EB (2000) Phylum Ciliophora. In: Lee JJ, Leedale GF, Bradbury P (eds) An illustrated guide to the Protozoa, 2nd edn. Society of Protozoologists, Lawrence, $\mathrm{KS}, \mathrm{p} 371-656$

Mathes J, Arndt H (1994) Biomass and composition of protozooplankton in relation to lake trophy in north German lakes. Mar Microb Food Webs 8:357-375

Müller H (1989) The relative importance of different ciliate taxa in the pelagic food web of Lake Constance. Microb Ecol 18:261-273

Müller H (1991) Pseudobalanion planctonicum (Ciliophora, Prostomatida): ecological significance of an algivorous nanociliate in a deep meso-eutrophic lake. J Plankton Res 13:247-262

Müller H (1996) Encystment of the freshwater ciliate Pelagostrombidium fallax (Ciliophora, Oligotrichida) in laboratory culture. Aquat Microb Ecol 11:289-295

Müller H, Schlegel A (1999) Responses of three freshwater planktonic ciliates with different feeding modes to cryptophyte and diatom prey. Aquat Microb Ecol 17:49-60

Müller H, Weisse T (1994) Laboratory and field observations on the scuticociliate Histiobalantium from the pelagic zone of Lake Constance, FRG. J Plankton Res 16: 391-401

Müller H, Schöne A, Pinto-Coelho RM, Schweizer A, Weisse $\mathrm{T}$ (1991) Seasonal succession of ciliates in Lake Constance. Microb Ecol 21:119-138

Pace ML (1986) An empirical analysis of zooplankton community size structure across lake trophic gradients. Limnol Oceanogr 31:45-55

Pace ML, Funke E (1991) Regulation of planktonic microbial communities by nutrients and herbivores. Ecology 72 : 904-914

Pfister G, Auer B, Arndt H (2002) Pelagic ciliates (Protozoa, Ciliophora) of different brackish and freshwater lakes - a community analysis at the species level. Limnologica 32: $147-168$

Sanders RW, Wickham SA (1993) Planktonic protists and metazoa: predation, food quality and population control. Mar Microb Food Webs 7:197-223

Scheffer M, Straile D, van Nes EH, Hosper H (2001) Climatic warming causes regime shifts in lake food webs. Limnol Oceanogr 46:1780-1783

Sharma S (1996) Applied multivariate techniques. John Wiley \& Sons, New York

Šimek K, Vrba J, Hartman P (1994) Size-selective feeding by Cyclidium sp. on bacterioplankton and various sizes of cultured bacteria. FEMS Microbiol Ecol 14:157-168

Šimek K, Bobková J, Macek M, Nedoma J, Psenner R (1995) Ciliate grazing on picoplankton in a eutrophic reservoir during the summer phytoplankton maximum: a study at the species and community level. Limnol Oceanogr 40: $1077-1090$

Šimek K, Macek M, Pernthaler J, Straskrabová V, Psenner R (1996) Can freshwater planktonic ciliates survive on a diet of picoplankton? J Plankton Res 18:597-613

Sommer U, Gliwicz ZM, Lampert W, Duncan A (1986) The PEG-model of seasonal succession of planktonic events in fresh waters. Arch Hydrobiol 106:433-471

Stoecker DK, Evans GT (1985) Effects of protozoan herbivory 
and carnivory in a microplankton food web. Mar Ecol Prog Ser 25:159-167

Stoecker DK, Gallager SM, Langdon CJ, Davis LH (1995) Particle capture by Favella sp. (Ciliata, Tintinnina). J Plankton Res 17:1105-1124

Stich B (in press) The reappearance of Diaphanosoma brayurum in Lake Constance. Arch Hydrobiol

Straile D (2000) Meteorological forcing of plankton dynamics in a large and deep continental European lake. Oecologia 122:44-50

Straile D (2002) North Atlantic Oscillation synchronises food web interactions in Central European lakes. Proc R Soc Lond B 269:391-395

Straile D, Geller W (1998) Crustacean zooplankton in Lake Constance from 1920 to 1995: response to eutrophication and re-oligotrophication. Arch Hydrobiol Spec Iss Adv Limnol 53:255-274

Tessier A, Woodruff JP (2002) Cryptic trophic cascade along a gradient of lake size. Ecology 83:1263-1270

Wacker A, von Elert E (2001) Constraints at the primary producer-consumer interface due to fatty acids: evidence for non-substitutable biochemical resources in Daphnia galeata. Ecology 82:2507-2520

Washington HG (1984) Diversity, biotic and similarity indices. A review with special relevance to aquatic ecosystems. Water Res 18:653-694

Editorial responsibility: Robert Sanders

Philadelphia, Pennsylvania, USA
Weisse T, Müller H (1998) Planktonic protozoa and the microbial food web in Lake Constance. Arch Hydrobiol Spec Iss Adv Limnol 53:223-254

Weisse T, Karstens N, Meyer VCL, Janke L, Lettner S, Teichgräber K (2001) Niche separation in common prostome freshwater ciliates: the effect of food and temperature. Aquat Microb Ecol 26:167-179

Wiackowski K, Brett MT, Goldman CR (1994) Differential effects of zooplankton species on ciliate community structure. Limnol Oceanogr 39:486-492

Wickham SA (1995a) Cyclops predation on ciliates: speciesspecific differences and functional responses. J Plankton Res 17:1633-1646

Wickham SA (1995b) Trophic relations between cyclopoid copepods and ciliated protists: complex interactions link the microbial and classic food webs. Limnol Oceanogr 40: 1173-1181

Wickham SA, Gilbert JJ (1991) Relative vulnerabilities of natural rotifer and ciliate communities to cladocerans: laboratory and field experiments. Freshw Biol 26:77-86

Wickham SA, Gilbert JJ (1993) The comparative importance of competition and predation by Daphnia on ciliated protists. Arch Hydrobiol 126:289-313

Zingel P, Huitu E, Mäkelä S, Arvola L (2002) The abundance and diversity of planktonic ciliates in 12 boreal lakes of varying trophic state. Arch Hydrobiol 155:315-332

Submitted: June 12, 2003; Accepted: October 10, 2003

Proofs received from author(s): February 16, 2004 